
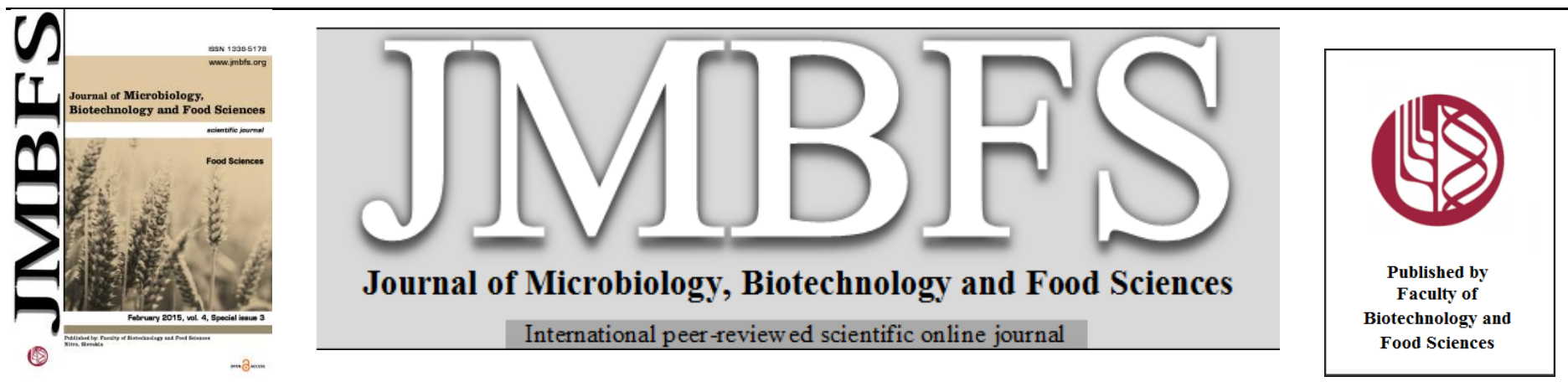

\title{
COLOUR, PHENOLIC CONTENT AND ANTIOXIDANT ACTIVITY OF THE SLOVAK ALIBERNET RED WINE SAMPLES
}

\author{
Daniel Bajčan** ${ }^{l}$, Vladimír Šimanský², Tomáš Tóth ${ }^{\text {, }}$, Július Árvay ${ }^{1}$ \\ Address(es): RNDr. Daniel Bajčan, PhD. \\ ${ }^{1}$ Slovak University of Agriculture, Nitra, Faculty of Biotechnology and Food Sciences, Department of Chemistry, Tr. A. Hlinku 2, 94976 Nitra, Slovak Republic. \\ ${ }^{2}$ Slovak University of Agriculture, Faculty of Agrobiology and Food Resources, Department of Pedology and Geology, Tr. A. Hlinku 2, 94976 Nitra, Slovak Republic.
}

*Corresponding author: bajcan@gmail.com

doi: 10.15414/jmbfs.2015.4.special3.5-8

\section{ARTICLE INFO}

Received 4. 12. 2014

Revised 17. 12. 2014

Accepted 18. 12. 2014

Published 2. 2. 2015

Regular article

open $\odot$ access

\begin{abstract}
Sixteen Alibernet wine samples, originated from three most important Slovak vineyard regions, were evaluated spectrophotometrically for the content of total polyphenols, content of total anthocyanins, antioxidant activity and wine colour density. The determined total polyphenol contents in observed wines ranged from 2141 to $4274 \mathrm{mg}$ gallic acid per liter (average content was $3057 \mathrm{mg}$ gallic acid/L) and total anthocyanin contents ranged from 73.4 to $791.2 \mathrm{mg} / \mathrm{L}$ (average content was $403.4 \mathrm{mg} / \mathrm{L}$ ). Determined values of antioxidant activity were within the interval $54.8-86.8 \%$ (average value was $74.5 \%$ ) and the values of wine colour density varied between 0.944 and 4.592 (average value was 2.317). The statistical evaluation of the obtained results confirmed only weak linear correlation between total polyphenol content and total anthocyanin content, however strong linear correlations between total anthocyanin content and antioxidant activity, resp. wine colour density were observed. Our results also confirmed very highly significant linear relationship between wine colour density and total polyphenol content, resp. antioxidant activity and between antioxidant activity and total phenolic content.
\end{abstract}

Keywords: Polyphenols, anthocyanin, antioxidant activity, red wine, Alibernet

\section{INTRODUCTION}

In recent years healthy effects of moderate consumption of wine have been discussed by scientific as well as laic community. Wine is considered to be an important source of antioxidants among beverages in human nutrition (Faitová $\boldsymbol{e}$ al., 2004). Drinking of wine has a lot of positive effects on health of human population, while wine becomes the part of healthy life style. More than 500 various compounds (saccharides, acids, tannins, vitamins, phenolic compounds...) are present in wine. Polyphenolic compounds are very monitored and discussed group of antioxidants in wine that exert bio-protective effects and have strongly positive effect on human health. Their importance is in reducing of cardiovascular and carcinogenic diseases incidence (Slezák, 2007).

Phenolic compounds, as secondary metabolites, rank among phytochemicals groups, and have physiological and morphological importance for plants. From the standpoint of structure phenolic compounds consist of minimally one aromatic ring with one or more substitution $-\mathrm{OH}$ groups and form numerous and subsequently diversified group of substances including substances from simple phenolic to polymerized phenolic compounds. This is the reason why they are called polyphenols. Plant polyphenols are amorphous substances occurring almost in all plants, especially in leaves, flowers, seeds, fruits, in pathologic formations, as well as in products of plant origin, honey, propolis and wine. They are present mainly in form of conjugates of saccharides molecules in plants, with one or more phenolic molecules or they occur in form of functional derivatives, such as esters or metylesters (Balasundram et al., 2006; Vollmanová et al. 2009; Timoracká, 2010).

Globally, red wines contain more phenolic compounds than white wines. It is caused by the technology of winemaking, when making white wines the grapes' skin is removed before fermentation (Beer $\boldsymbol{e t}$ al., 2006). The total polyphenols in wine besides variety of grapes, locality of growing, climatic conditions, are affected also by procedure of winemaking: length of contact of stum with grapes's skin, mixing, temperature, content of $\mathrm{SO}_{2}, \mathrm{pH}$ value, content of alcohol etc. (Villano et al., 2006; Lachman and Šulc, 2006).

Variety Alibernet originated from crossing of varieties Alicante Bouchet $\mathrm{x}$ Cabernet Sauvignon in Ukraine in 1950. Alibernet name is derived from the names of two parental varieties. High harvest, higher acids content, lower sugar contents and very high dye content is typical for this grape variety. Must has significant Cabernet taste (Pospíšilová, 2003). Alibernet is little widespread variety in Europe and is grown mainly in warmer locations in Slovakia and South
Moravia. In Slovakia, Alibernet grown at about 5.8\% of the areas planted with blue grapevine varieties and it is the fourth most cultivated blue variety after Blaufränkisch, St. Laurent and Cabernet Sauvignon (Šajbidorová, 2012).

The purpose of this study was to determine and evaluate chosen antioxidant and sensory properties (the content of total polyphenols, content of total anthocyans, antioxidant activity and wine colour density) and their mutual correlations in red wines - Alibernet, originated from different Slovak vineyard areas.

\section{MATERIAL AND METHODS}

\section{Chemicals and instruments}

All analysed parameters - total polyphenol content, total anthocyanin content, antioxidant activity and wine colour density in wines were analyzed by UV/VIS spectrophotometry (spectrophotometer Shimadzu UV/VIS - 1240, Shimadzu, Japan). The chemicals used for all analysis were: Folin-Ciocalteau reagent monohydrate of gallic acid p.a., anhydrous natrium carbonate p.a., citric acid p.a., dodecahydrate of disodium hydrogen phosphate, 35\% hydrochloric acid p.a., ethanol p.a., methanol p.a., 1,1-diphenyl-1-picrylhydrazyl (DPPH) radical p.a., Trolox (pure)

\section{Samples}

Analysed, bottled, red, especially quality and dry wines Alibernet and their characteristics are mentioned in Table 1. Wine samples with origin in various Slovak vineyard areas (VA) were purchased in retail network, to provide that analysed samples of wine would have the same properties as wines that are consumed by common consumers (properties of wine affected by various factors, such as period and conditions of storage or distribution of wine).

\section{Sample analysis}

Total polyphenol content (TPC) was determined by modified method of Singleton and Rossi (1965). $0.1 \mathrm{~mL}$ of wine sample was pipetted into $50 \mathrm{~mL}$ volumetric flask and diluted with $5 \mathrm{~mL}$ of distilled water. To diluted mixture 2.5 $\mathrm{mL}$ Folin-Ciocalteau reagent was added and after 3 minutes $7.5 \mathrm{~mL}$ of $20 \%$ solution of $\mathrm{Na}_{2} \mathrm{CO}_{3}$ was added. Then the sample was filled with distilled water to volume $50 \mathrm{~mL}$ and after mixing left at the laboratory temperature for 2 hours. By 
the same procedure the blank and calibration solutions of gallic acid were prepared. Absorbance of samples solutions was measured against blank at 765 nm. Total polyphenol (TP) content in wines was calculated as amount of gallic acid equivalent (GAE) in mg per 1 litre of wine.

Total anthocyanin content (TAC) was assessed by modified $\mathrm{pH}$ differential method of Lapornik et al. (2005). The principle of this method is reduction of the $\mathrm{pH}$ of wine samples with $\mathrm{HCl}$ solution to values $0.5-0.8$ associated with the transformation of all anthocyans to red colored flavilium cation. The total anthocyanin (TA) content was calculated from the difference absorbance values of both solutions and expressed as the amount of anthocyanins in $\mathrm{mg} / \mathrm{L}$ of wine. Antioxidant activity (AA) was assessed by method of Brand-Williams $\boldsymbol{e t}$ al (1995) using of DPPH (2,2-diphenyl-1-picrylhydrazyl) radical. Absorbance was read at $515.6 \mathrm{~nm}$ and antioxidant effectiveness was expressed as \% inhibition of DPPH (quantitative ability of tested compound to remove in certain period a part of DPPH radical) and also as Trolox equivalent calculated from calibration curve.

Table 1 Characteristics of analysed Alibernet red wine samples

\begin{tabular}{|c|c|c|c|c|}
\hline Sample & Producer & Vineyard area & Vintage & Quality \\
\hline A-LC-1 & Vitis Pezinok, s.r.o. / Hubert J.E. Sered' & Little Carpathian & 2011 & quality \\
\hline A-LC-2 & Malokarpatská vinohradnícka spol., a.s., Pezinok & Little Carpathian & 2011 & quality \\
\hline A-LC-3 & Víno Sabo, Vrbové & Little Carpathian & 2011 & quality \\
\hline A-LC-4 & JM Vinárstvo Dol'any, Dol'any & Little Carpathian & 2009 & grape selection \\
\hline A-SS-1 & Vinárske závody Topol’čianky, s.r.o., Topol'čianky & South Slovak & 2010 & quality \\
\hline A-SS-2 & Víno Nitra, s.r.o., Nitra & South Slovak & 2011 & quality \\
\hline A-SS-3 & VVD, Dvory nad Žitavou & South Slovak & 2011 & quality \\
\hline A-SS-4 & Virex, s.r.o., Nesvady & South Slovak & 2011 & quality \\
\hline A-SS-5 & Chateu Modra, a.s., Modra & South Slovak & 2010 & late harvest \\
\hline A-SS-6 & Villa Víno Rača, a.s., Bratislava & South Slovak & 2011 & quality \\
\hline A-SS-7 & Vinárske závody Topol’čianky, s.r.o., Topol’čianky & South Slovak & 2009 & late harvest \\
\hline A-N-1 & Vinárske závody Topol’čianky, s.r.o., Topol'čianky & Nitra & 2007 & quality \\
\hline A-N-2 & VINIDI, s.r.o., Bratislava & Nitra & 2008 & late harvest \\
\hline A-N-3 & Vinárske závody Topol’čianky, s.r.o., Topol’čianky & Nitra & 2012 & quality \\
\hline A-N-4 & Vinárstvo Trnovec, Nitra & Nitra & 2012 & grape selection \\
\hline A-N-5 & Muráni-Víno Čajkov, s.r.o., Čajkov & Nitra & 2012 & quality \\
\hline
\end{tabular}

Wine colour density (WCD) was assessed by method of Sudrand (1958) as the sum of the absorbance at $420 \mathrm{~nm}$ and $520 \mathrm{~nm}$. The absorbance of the wine samples was measured in $0.2 \mathrm{~cm}$ path length glass cells.

All chemical analyses were performed as four parallels.

\section{Statistical analysis}

Statistical analysis was performed using the software Statistica 6.0 (StatSoft) and the results were evaluated by analysis of variance ANOVA.

\section{RESULTS AND DISCUSSION}

All studied parameters - the content of total polyphenols, the content of total anthocyanins, antioxidant activity and wine colour density of the Slovak red wines Alibernet are described in Table 2.

Total polyphenol content in analysed wine samples was in the range from 2064 to $4274 \mathrm{mg}$ GAE/L. Average content of TP was $3057 \mathrm{mg}$ GAE/L. The average content of total polyphenols in wines - Alibernet is much higher than we found out in the other three major Slovak varietal red wines Blaufränkisch - $2003 \mathrm{mg}$ GAE/L, Saint Laurent - 2297 mg GAE/L and Cabernet Sauvignon - 2407 mg

GAE/L (Bajčan et al., 2012a,b). Our results are slightly lower than results reported by Slezák (2007) and Čižmárová (2009), who found out the content of TP in slovak wines - Alibernet in range from 2865 to $5340 \mathrm{mg}$ GAE/L. According to the average value of TPC an order for wines could be as following: wines from Nitra VA > wines from South Slovak VA > wines from Little Carpathian VA. Gained results did not exert statistically significant differences ( $P$ $<0.05)$ between TPC in wines made in various vineyard areas in Slovakia.

Total anthocyanin content in analysed wine samples was in the range from 73.4 to $791 \mathrm{mg} / \mathrm{L}$. Average content of TA was $422 \mathrm{mg} / \mathrm{L}$. The average TAC in wines Alibernet is significantly higher than we found out in the other three major Slovak varietal red wines Blaufränkisch - $266.1 \mathrm{mg} / \mathrm{L}$, St. Laurent - $264 \mathrm{mg} / \mathrm{L}$ and Cabernet Sauvignon - $209.3 \mathrm{mg} / \mathrm{L}$ (Tóth et al., 2011; Bajčan et al., 2012b). Our results of TAC in wines Alibernet cannot be compared with other authors, because they used different methods for the determination of TA. According to the average value of TAC an order for wines could be as following: wines from Nitra VA > wines from Little Carpathian VA > wines from South Slovak VA. Our results also did not exert statistically significant differences between TAC in wines made in various vineyard areas in Slovakia.

Antioxidant activity in analysed wine samples was in range $54.8-86.8 \%$ inhibition of DPPH (resp. $0.627-1.101 \mathrm{mmol}$ Trolox/L). Average value of AA was $74.5 \%$ inhibition of DPPH (resp. $0.903 \mathrm{mmol}$ Trolox/L). The average value of AA in Alibernet wines is a slightly lower than we found out in the other three major Slovak red wines Blaufränkisch $-83.3 \%$, St. Laurent $-81.2 \%$ and Cabernet Sauvignon - 78.8\% inhibition of DDPH (Bajčan et al., 2012a,b) Slezák (2007) and Čižmárová (2009) reported lower values of AA and they found out AA in slovak wines - Alibernet in range from 61 to $65.1 \%$ inhibition of DPPH. On the basis of value of AA an order could be as following: wines from South Slovak VA > wines from Little Carpathian VA > wines from Nitra VA Gained results did not exert statistically significant differences between values of antioxidant activity in wines made in various vineyard areas in Slovakia.

Wine colour density in analysed wine samples was in range from 0.944 to 4.592 . Average value of WCD was 2.317. The average value of WCD in wines Alibernet was much higher than we found out in the other three major Slovak varietal red wines Blaufränkisch -1.110 , St. Laurent -1.224 and Cabernet Sauvignon - 1.364 (Tóth et al., 2011; Bajčan et al., 2012b). This work is the first study monitoring WCD in Slovak wines Alibernet so we can't compare our data with other local scientists. According to the average value of WCD an order for wines could be as following: wines from Nitra VA > wines from Little Carpathian VA > wines from South Slovak VA. Gained results did not exert statistically significant differences between values of WCD in wines made in various vineyard areas in Slovakia. 
Table 2 The content of total polyphenols (TPC), content of total anthocyanins (TAC), antioxidant activity (AA) and wine colour density (WCD) in analysed wines

\begin{tabular}{|c|c|c|c|c|c|}
\hline Sample & $\begin{array}{c}\text { TPC } \\
(\mathrm{mg} \mathrm{GAE} / 1)\end{array}$ & $\begin{array}{c}\text { TAC } \\
(\mathrm{mg} / \mathrm{l})\end{array}$ & $\begin{array}{l}\mathbf{A A} \\
(\%)\end{array}$ & $\begin{array}{c}\text { AA } \\
(\mathrm{mmol} \text { Trolox } / \mathrm{l})\end{array}$ & WCD \\
\hline A-LC-1 & $2141 \pm 23$ & $262 \pm 4.0$ & $83.2 \pm 1.4$ & $1.038 \pm 0.017$ & $1.374 \pm 0.026$ \\
\hline A-LC-2 & $3218 \pm 23$ & $509 \pm 6.1$ & $65.2 \pm 1.4$ & $0.762 \pm 0.017$ & $3.514 \pm 0.034$ \\
\hline A-LC-3 & $3052 \pm 45$ & $791 \pm 14.1$ & $74.4 \pm 2.8$ & $0.895 \pm 0.035$ & $2.482 \pm 0.021$ \\
\hline A-LC-4 & $2409 \pm 61$ & $73.4 \pm 1.4$ & $78.7 \pm 0.7$ & $0.962 \pm 0.008$ & $1.502 \pm 0.015$ \\
\hline Average LCVA & $2705 \pm 523^{a}$ & $409 \pm 349^{\mathrm{a}}$ & $75.4 \pm 8.7^{a}$ & $0.914 \pm 0.134^{\mathrm{a}}$ & $2.218 \pm 1.039^{\mathrm{a}}$ \\
\hline A-SS-1 & $2929 \pm 23$ & $416 \pm 6.3$ & $80.9 \pm 0.5$ & $0.999 \pm 0.006$ & $1.782 \pm 0.021$ \\
\hline A-SS-2 & $2064 \pm 23$ & $218 \pm 4.2$ & $86.8 \pm 0.9$ & $1.101 \pm 0.011$ & $0.944 \pm 0.014$ \\
\hline A-SS-3 & $3834 \pm 23$ & $664 \pm 7.0$ & $63.3 \pm 1.1$ & $0.736 \pm 0.014$ & $3.781 \pm 0.012$ \\
\hline A-SS-4 & $2847 \pm 45$ & $441 \pm 5.5$ & $80.3 \pm 0.5$ & $0.989 \pm 0.006$ & $1.779 \pm 0.008$ \\
\hline A-SS-5 & $2618 \pm 70$ & $192 \pm 3.7$ & $82.7 \pm 0.6$ & $1.029 \pm 0.007$ & $1.436 \pm 0.009$ \\
\hline A-SS-6 & $2487 \pm 70$ & $458 \pm 5.3$ & $78.8 \pm 0.8$ & $0.964 \pm 0.010$ & $1.862 \pm 0.019$ \\
\hline A-SS-7 & $3895 \pm 45$ & $318 \pm 5.3$ & $69.2 \pm 1.0$ & $0.818 \pm 0.012$ & $2.815 \pm 0.025$ \\
\hline Average SSVA & $2953 \pm 677^{b}$ & $387 \pm 175^{b}$ & $77.4 \pm 8.7^{b}$ & $0.948 \pm 0.135^{\mathrm{b}}$ & $2.057 \pm 1.051^{\mathrm{b}}$ \\
\hline A-N-1 & $3158 \pm 92$ & $92.8 \pm 5.9$ & $78.4 \pm 0.5$ & $0.958 \pm 0.006$ & $1.629 \pm 0.016$ \\
\hline A-N-2 & $4066 \pm 23$ & $322 \pm 4.2$ & $61.6 \pm 1.5$ & $0.714 \pm 0.019$ & $3.309 \pm 0.024$ \\
\hline A-N-3 & $3013 \pm 23$ & $328 \pm 6.1$ & $76.3 \pm 0.5$ & $0.924 \pm 0.006$ & $2.015 \pm 0.018$ \\
\hline A-N-4 & $2908 \pm 23$ & $635 \pm 5.6$ & $76.9 \pm 0.6$ & $0.934 \pm 0.007$ & $2.260 \pm 0.023$ \\
\hline A-N-5 & $4274 \pm 68$ & $732 \pm 7.1$ & $54.8 \pm 1.4$ & $0.627 \pm 0.017$ & $4.592 \pm 0.015$ \\
\hline Average NVA & $3484 \pm 587^{c}$ & $422 \pm 275^{c}$ & $69.6 \pm 10.1^{c}$ & $0.831 \pm 0.142^{c}$ & $2.761 \pm 1.274^{\mathrm{c}}$ \\
\hline Total average & $3057 \pm 668$ & $403 \pm 219$ & $74.5 \pm 9.0$ & $0,903 \pm 0.134$ & $2.317 \pm 1.019$ \\
\hline
\end{tabular}

Legend: LCVA - Little Carpathian vineyard area, SSVA - South Slovak vineyard area, NVA - Nitra vineyard area.

Values of TPC, TAC, AA and WCD are expressed as arithmetic average \pm standard deviation,

${ }^{\mathrm{a}-\mathrm{c}}$ Values with the same letters denote significant differences $(\mathrm{P}<0.05)$ among vineyard areas.

In order to investigate the mutual relations between analyzed parameters, the linear regressions were obtained. The statistical evaluation of the obtained results confirmed only weak linear correlation between TPC and TAC ( $\mathrm{r}=0.447, \mathrm{P}<$ 0.1). This is not in agreement with our previous study (Bajčan et al., 2012b), where we found out strong linear correlation $(r=0.542, \mathrm{P}<0.01)$ between TPC and TAC in red wines - Cabernet Sauvignon. Cioroi and Musat (2007) also reported very strong correlation between TPC and TAC $(r=0.739$ and 0.771$)$ in red wines. The correlations between TAC and AA $(r=-0.532)$, resp. TAC and WCD $(r=0.660)$ were strong at significance level $\mathrm{P}<0.01$. Other authors (Burin et al., 2010; Cioroi and Musat, 2007; Balík et al., 2008) also found out very strong linear correlations between TAC and AA in wines and grape juices. The statistical evaluation of the obtained results confirmed very strong correlations between AA and TPC $(r=-0.917, \mathrm{P}<0.001)$, WCD and TPC $(r=0.887, \mathrm{P}$ $0.001)$, resp. WCD and $\mathrm{AA}(\mathrm{r}=-0.979, \mathrm{P}<0.001)$. Similary very strong correlations between AA and TPC found out other researchers (Burin et al., 2010; Cioroi and Musat, 2007; Kondrashov et al., 2009; Balík et al., 2008) Very strong correlations between WCD and TPC, resp. WCD and AA in red wines (Cabernet Sauvignon) we also reported in our previous study (Bajčan et al., 2012b).

\section{CONCLUSION}

In the present study we showed that Slovak red wines - Alibernet had high content of healthy useful polyphenols (average value of TPC $3057 \mathrm{mg}$ GAE/L), high antioxidant activity (average value of AA 74.5\% inhibition of DPPH), high content of total anthocyanins (average value of TAC $403 \mathrm{mg} / \mathrm{L}$ ) and extremely intensive red colour (average value of WCD 2.317). The results did not showed statistically significant differences for all four studied parameters (TPC, TAC AA and WCD) in wines made in three different vineyard areas in Slovakia. On the basis of statistical evaluation of our results we can state, that there are statistically highly significant or very highly significant linear correlations between all studied parameters (excepting correlation between total phenolic content and total anthocyanin content) of Alibernet wines.

Acknowledgements: This work was financially supported by the Slovak Science Foundation VEGA (Grant no. 1/0630/13).

\section{REFERENCES}

BAJČAN, D., ČÉRYOVÁ, S., TOMÁŠ, J. 2012a. Antioxidant properties of the bestselling Slovak red wines. Journal of Microbiology, Biotechnology and Food Sciences, 1, 455-465.

BAJČAN, D., ŠIMANSKÝ, V., TÓTH, T., TIMORACKÁ, M., HARANGOZO, L. 2012b. Chosen antioxidant and sensory properties and their mutual relations of slovak red wines - Cabernet Sauvignon. Chemical reaction in Foods VII (Proceedings of the work of the International Scientific Conference) Prague: Institute of chemical technology, 101. ISBN 978-80-7080-836-8

BALASUNDRAM, N., SUNDRAM, K., SAMMAN, S. 2006. Phenolic compounds in plants and agri-industrial by-products: Antioxidant activity, occurrence, and potential uses. Food Chemistry, 99, 191-203. http://dx.doi.org/10.1016/j.foodchem.2005.07.042

BALÍK, J., KYSELÁKOVÁ, M., VRCHOTOVÁ, N., TŘÍSKA, J., KUMŠTA M., VEVERKA, J., HÍC, P., TOUŠEK, J., LEFNEROVÁ, D. 2008. Relations between polyphenols content and antioxidant activity in vine grapes and leaves. Czech Journal of Food Science, 26, S25-S32

BEER, D., JOUBERT, E., MARAIS, J., MANLEY, M. 2006. Unravelling the total antioxidant capacity of Pinotage wine: contribution of phenolic compounds Journal of Agricultural and Food Chemistry, 54, 2897-2905. http://dx.doi.org/10.1021/jf052766u

BRAND-WILLIAMS, W., CUVELIER, M. E., BERSET, C. 1995. Use of a free radical method to evaluate antioxidant activity. Lebensmittel Wissenschaft und Technologie, 28, 25-30. http://dx.doi.org/10.1016/s0023-6438(95)80008-5

BURIN, V.M., FALCAO, L.D., GONZAGA, L.V., FETT, R., ROSIER, J.P., BORDIGNON-LUIZ, M.T. 2010. Colour, phenolic content and antioxidan activity of grape juice. Ciencia e Technologia de Alimentos, 30(4), 1027-1032. http://dx.doi.org/10.1590/s0101-20612010000400030

CIOROI, M., MUSAT, C.L. 2007. Investigations on the correlations between polyphenol content from red wines and their antioxidant activity. Cercetari Agronomice in Moldova, 4, 35-41.

ČIŽMÁROVÁ, M. 2009. Antioxidant and antiradical activity of chosen types of wine. Dissertation, Nitra: Slovak University of Agriculture, 2009, 168 p.

FAITOVÁ, K., HEJTMÁNKOVÁ, A., LACHMAN, J., PIVEC, V., DUDJAK, J 2004. The contentsof total polyphenolic compounds and trans-resveratrol in white riesling originated in the Czech repuplic. Czech Journal of Food Science, 226, 215-221.

KONDRASHOV, A., ŠEVČÍK, R., BENÁKOVÁ, H., KOSTÍŘOVÁ, H ŠTÍPEK, S. 2009. The key role of grape variety for antioxidant capacity of red wines. The European e-Journal of Clinical Nutrition and Metabolism, 4, e41-e46. 
http://dx.doi.org/10.1016/j.eclnm.2008.10.004

LACHMAN, J., ŠULC, M. 2006. Phenolics and antioxidant activity of wines during the winemaking process. Bornimer Agrartechnische Berichte, 55, 161168.

LAPORNIK, B., PROŠEK, M., WONDRA, A.G. 2005. Comparison of extracts prepared from plant by-products using different solvents and extraction time. Journal of Food Engineering, 71, 214-222. http://dx.doi.org/10.1016/j.jfoodeng.2004.10.036

POSPÍŠILOVẢ, D. 2003. Alibernet. Vinič a Vino, 3 (3), $83-84$ (in Slovak)

SINGLETON, V.L., ROSSI, J.A. 1965. Colorimetry of total phenolics with phosphomolybdic-phosphotungstic acid reagents. American Journal of Enology and Viticulture, 16, 14-158.

SLEZÁK, F. 2007. Preserving of antioxidant components in wines from Little Carpathian region. Research report, Modra: Biocentrum Modra and VÚP Bratislava, 19 p. (in Slovak)

SUDRAND, P. 1958. Interpretation des d'absorption des vins rouges. An Technology and Agriculture, 7, 203-208.

ŠAJBIDOROVÁ, V. 2012. Grapes, grape wine - situation and outlook report to 31. 7. 2012. Bratislava: Research Institute of Agricultural and Food Economics, 40 p. (in Slovak)

TIMORACKÁ, M. 2010. Polyphenolic substances. Biology, ecology, chemistry, $14,10-14$

TÓTH, T., BAJČAN, D., VOLLMANNOVÁ, A., TREBICHALSKÝ, P., LAHUČKÝ, L., MIŠŠÍK, J. 2011. The phenolic content and antioxidant activity of varietal slovak red wines. Chemiské Listy, 105, 1029.

VILLANO, D., FERNÁNDEZ-PACHÓN, M.S., TRONCOSO, A.M., GARCÍAPARRILLA, M.C. 2006. Influence of enological practices on the antioxidant capacity and total polyphenols. Food Chemistry, 95, 394-404. http://dx.doi.org/10.1016/j.foodchem.2005.01.005

VOLLMANNOVÁ, A, TOMÁŠ, J, URMINSKÁ, D, POLÁKOVÁ, S. MELICHÁČOVÁ, S., KRÍŽOVÁ, L. 2009. Content of bioactive components in chosen cultivars of cranberries (Vaccinium vitis-idea L.). Czech Journal of Food Science, 27, S248-S251.

LEITCH, D.R., CARRIE, J., LEAN, D., MACDONALD, R.W., STERN, G.A., WANG, F.Y. 2007. The delivery of mercury to the Beaufort Sea of the Arctic Ocean by the Mackenzie River. Science of the total environment, 373, 178-195. http://dx.doi.org/doi:10.1016/j.scitotenv.2006.10.041

LI, Y., GOU, X., WANG, G., ZHANG, Q., SU, Q., XIAO, G. 2008. Heavy metal contamination and source in arid agricultural soil in Central Gansu Province, China. Journal of environmental science, 20(5), 607-612.

RODRIGUES, S., PEREIRA, M.E., SARABANDO, L., CACHADA, A., DUARTE, A. 2006. Spatial distribution of total $\mathrm{Hg}$ in urban soils from an Atlantic coastal city (Aveiro, Portugal). Science of the total environment, 368, $40-46$

http://dx.doi.org/10.1016/j.scitotenv.2005.09.088

STREETS, D.G., HAO, J., WU, Y., JIANG, J., CHAN, M., TIAN, H., FENG, X. 2005. Anthropogenic mercury emissions in China. Atmospheric environment, 39 7789-7806. http://dx.doi.org/10.1016/j.atmosenv.2005.08.029

WANG, X.M., ZHANG, J., WU L.H., ZHAO, Y.L., LI, T., LI, J.Q., WANG, Y.Z., LIU, H.G. 2014. A mini-review of chemical composition and nutritional value of edible wild-grown mushroom from China. Food Chemistry, 151, 279285.

http://dx.doi.org/10.1016/j.foodchem.2013.11.062.

WHO, 1993. Evaluation of certain food additives and contaminants, $41^{\text {st }}$ Report of the Joint FAO/WHO Expert Committee on Food Additives. Technical Reports Series No 837. World Health Organization, Geneva (Switzerland). 